LETTER - Theor. Chem. Acc. - TCAC-D-19-00076

\title{
Unravelling the reaction mechanism for the Claisen-Tishchenko condensation catalysed by Mn(I)-PNN complexes: A DFT study
}

\author{
Luis Miguel Azofra ${ }^{\mathrm{a}, \mathrm{b}, *}$ and Luigi Cavallo ${ }^{\mathrm{c}, *}$ \\ ${ }^{a}$ CIDIA-FEAM (Unidad Asociada al Consejo Superior de Investigaciones Científicas, CSIC, avalada por \\ el Instituto de Ciencia de Materiales de Sevilla, Universidad de Sevilla), Instituto de Estudios \\ Ambientales y Recursos Naturales (i-UNAT), Universidad de Las Palmas de Gran Canaria (ULPGC), \\ Campus de Tafira, 35017, Las Palmas de Gran Canaria, Spain \\ bepartamento de Química, Universidad de Las Palmas de Gran Canaria (ULPGC), Campus de Tafira, \\ 35017, Las Palmas de Gran Canaria, Spain \\ ${ }^{c}$ KAUST Catalysis Center (KCC), King Abdullah University of Science and Technology (KAUST), \\ Thuwal 23955-6900, Saudi Arabia \\ *E-mails: luismiguel.azofra@ulpgc.es, luigi.cavallo@kaust.edu.sa \\ TCA Special issue of the ESPA 2018 Conference \\ (Dedicated to Prof. Dr. Otilia Mó and Prof. Dr. Manuel Yáñez on occasion of their $70^{\text {th }}$ birthdays)
}

KEYWORDS: manganese complexes $\bullet$ PNN ligands $\bullet$ homogeneous catalysis $\bullet$ esters $\bullet$ DFT

\begin{abstract}
In this work, we study the potential catalytic role of previously identified $\mathrm{Mn}(\mathrm{I})-$ PNN complexes in the Claisen-Tishchenko reaction. An in-depth investigation of the reaction mechanism suggests that, after activation of the 16e pre-catalyst, a hydrogenated 18e active species is generated. Based on calculations, rate-limiting barriers in a range of $c a$. 15-20 kcal $\mathrm{mol}^{-1}$ are seen for a model process consisting in the esterification of acetaldehyde into ethyl acetate at $100{ }^{\circ} \mathrm{C}$ and $1 \mathrm{~atm}$ reaction conditions (in toluene solution). Our hypothesis is centred on the role of the Mn centre as the only active site involved in both elementary steps, namely hydride borrowing and $\mathrm{C}-\mathrm{O}$ bond formation. During this $\mathrm{C}-\mathrm{O}$ bond formation step, diastereoisomers $\left(R_{N}, R\right)$ and $\left(R_{N}, S\right)$ [or their enantiomeric pairs $\left(S_{N}, S\right)$ and $\left(S_{N}, R\right)$ ] can be generated, with calculations showing a preference towards the $\left(R_{N}, R\right)$ pathway.
\end{abstract}




\section{GRAPHICAL ABSTRACT}

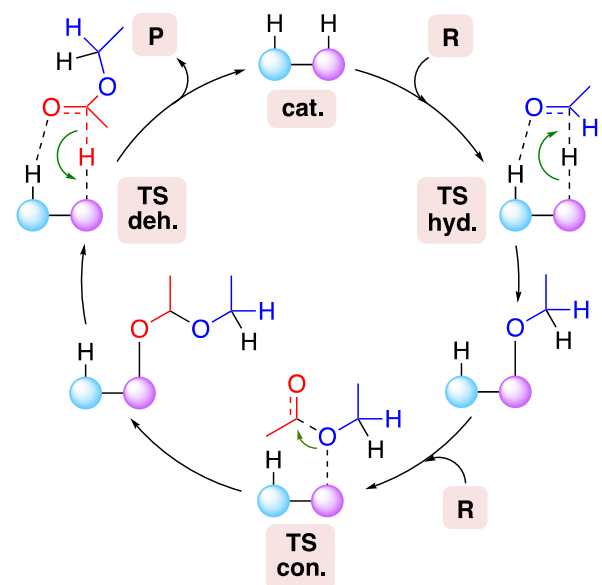




\section{INTRODUCTION}

Esters are fundamental chemical functionalities that are present in multitude of essential and artificial compounds. Glycerides, for example, which are special kinds of esters formed from glycerol and fatty acids, constitute a main class of biological lipids, and phosphoesters play a fundamental role as backbones of the strands in DNA and RNA nucleic acids. Other compounds such as polyesters, with polyethylene terephthalate (PET) as the most commonly referred of these materials, are man-made polymers containing esters functional groups linking the monomeric units. In general rules, the role of esterification in the field of organic synthesis is certainly unquestionable. ${ }^{1}$

Amongst the advances in the design of novel organometallic catalysts for organic synthesis, the replacement of precious metals by earth-abundant and more environmentally benign base metals has attracted much attention. ${ }^{2}$ A particularly interesting case illustrating this tendency can be seen in the development of homogeneous catalysts capable of assist in the reduction of alkynes into olefins. Thus, at late 70s, Schrock and Osborn reported a set of rhodium hydrides complexes, ${ }^{3}$ and two decades later, Yamagata and Han described iridium- and palladium-based adducts. ${ }^{4,5}$ It is not until the recent years in which the employment of more accessible metals, such as ruthenium, nickel, cobalt, or copper, has been informed. ${ }^{6-9}$ In this line, our group has recently reported the first example of a manganese-based catalyst bearing PNP non-innocent ligands for highly chemo- and stereoselective semihydrogenation of alkynes into (Z)-alkenes. ${ }^{10}$

Because manganese is one of the cheapest base metals (with current market price of $c a .2$ $\$ / \mathrm{kg}$ ) and together with the fact that it has demonstrated to have a great catalytic potential, a plethora of novel catalysts have been developed using Mn as active centre for several organic transformations. Milstein and co-workers have proven the direct conversion of alcohols into alkenes using a series of Mn(I) complexes bearing PNP and PNN ligands, ${ }^{11}$ and Kirchner and co-workers have used similar type of catalysts for chemoselective hydrogenation of aldehydes into alcohols under mild and base-free conditions. ${ }^{12}$ It also highlights the works of Rueping et al. concerning the synthesis of pyrroles without generation of side products, ${ }^{13,14}$ or the production of amides by dehydrogenative coupling of alcohols and amines ${ }^{15}, 16$ and the alkylation of unactivated esters and amides with alcohols, ${ }^{17}$ amongst dozens of many examples in which (de)hydrogenation processes usually play a key mechanistic role. ${ }^{18,19}$ Early this year, Poater and co-workers have also delved into the mechanistic aspects of the manganese-pincer-catalysed dehydrogenative coupling of nitriles and alcohols and its related production of aldimines. ${ }^{20,21}$

One of the most interesting synthetic processes in organic chemistry lies in the formation of esters by condensation of aldehydes, with the Claisen ${ }^{22}$-Tishchenko reaction (see Scheme 1) representing an atom-efficient and waste-free procedure. ${ }^{23}$ The original approach developed by Tishchenko at the beginning of the last century mainly considered the use of aluminium alkoxide as catalyst, ${ }^{24,25}$ however and to-date, the representative number of materials containing 
transition metals as active sites remains surprisingly low. ${ }^{26-29}$ Amongst these advances, Morris and Gusev have recently reported that Os(II)-PNN and Os(II)-PNP complexes can catalyse the Claisen-Tishchenko reaction for a variety of substrates and achieving turnover numbers (TON) as high as $14000 \mathrm{~h}^{-1} .^{30}$

Scheme 1. Claisen-Tishchenko reaction.<smiles>[R2]COC(=O)[R]c1ccccc1</smiles>

Last year, in an attempt to stabilise a 16e $\mathrm{Mn}(\mathrm{I})$ complex bearing the oxygen sensitive $\mathrm{H}$ POP ligand, Lacy and co-workers serendipitously discovered the ability of this material to catalyse the Claisen-Tishchenko condensation of benzaldehyde to benzyl benzoate, ${ }^{31}$ and more recently, Milstein et al. have reported a novel system capable of produce esters via acceptorless dehydrogenation cross coupling of primary alcohols. ${ }^{32}$ For this last, the authors propose a plausible mechanism involving alcohol oxidation into aldehyde via rearomatisation of a dearomatised $\mathrm{P}^{\mathrm{pyr}} \mathrm{NN}$ ligand followed by hydride abstraction by action of the Mn active site. Subsequently, a nucleophilic attack with another alcohol molecule would be responsible to produce an ester previous release of a $\mathrm{H}_{2}$ molecule (two equivalents in overall).

Inspired by our recent progresses in the identification of a series of Mn(I)-PNN complexes as efficient catalysts for the hydrogenation of carbonates and polycarbonates into methanol and diols, ${ }^{33}$ in this work we also propose these series of catalysts for their application in the ClaisenTishchenko reaction of producing esters from aldehydes. For this purpose, the set of $\left.\left[\mathrm{Mn}^{(\mathrm{I})}(\mathrm{CO})_{2}\left({ }^{\mathrm{Ph}} \mathrm{PNN}\right)\right](\mathbf{M n 1}),\left[\mathrm{Mn}^{(\mathrm{I})}(\mathrm{CO})_{2}{ }^{i \mathrm{Pr} P N N}\right)\right](\mathbf{M n} 2)$, and $\left[\mathrm{Mn}^{(\mathrm{I})}(\mathrm{CO})_{2}\left({ }^{(\mathrm{Bu}} \mathrm{PNN}\right)\right](\mathbf{M n 3})$ complexes (see Scheme 2) have been selected and studied on a model system consisting in the esterification of acetaldehyde into ethyl acetate. Through DFT calculations, we propose an atom-efficient process that only requires the activation of the catalyst via single hydrogenation and in which the Mn centre is the only active site involved in both elementary steps, namely hydride borrowing and $\mathrm{C}-\mathrm{O}$ bond formation

Scheme 2. Set of Mn(I)-PNN complexes (Mn1-3) which have been selected to model the reaction mechanism of the Claisen-Tishchenko condensation of acetaldehyde into ethyl acetate. 


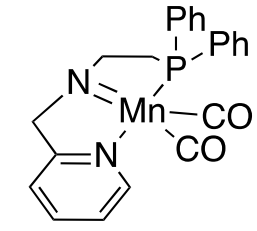

Mn1

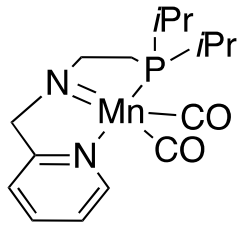

Mn2

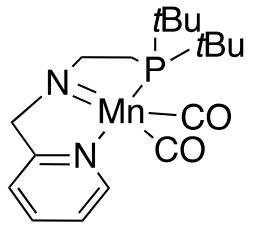

Mn3

\section{COMPUTATIONAL METHODS}

The reaction mechanism for the Claisen-Tishchenko reaction catalysed by a set of $\mathrm{Mn}(\mathrm{I})-\mathrm{PNN}$ complexes has been studied through the use of Density Functional Theory (DFT) via the spinrestricted Kohn-Sham (RKS) formalism and the $\omega$ B97XD functional, ${ }^{34}$ which includes GrimmeD2 empirical dispersion. ${ }^{35}$ The split-valence SVP basis set was used for non-metal atoms while the triple- $\xi$ TZVP basis set was employed for Mn. ${ }^{36}$ The EDIIS/CDIIS procedure ${ }^{37}$ was applied for the self-consistent field (SCF) convergence with ultrafine grid accuracy level. The Synchronous Transit-Guided Quasi-Newton (STQN) method $^{38}$ has been used to locate the transition states (TS). In all cases, frequency calculations were performed in order to confirm the nature of the stationary points (minima or first-order TSs with one imaginary frequency). To simulate the solvent effect, the Polarizable Continuum Model (PCM) ${ }^{39}$ has been used with the standard parameters for toluene $(\varepsilon=2.3741)$ at the optimisation stage. Gibbs energies have been computed at $100{ }^{\circ} \mathrm{C}$ and atmospheric pressure reaction conditions. All calculations were carried out through the facilities provided by the Gaussian09 package (revision D.01) ${ }^{40}$

\section{RESULTS AND DISCUSSION}

The selected groups of Mn(I)-PNN complexes (Mn1-3) shown at Scheme 2 are characterised to form a trigonal bipyramid structure around the Mn centre, being phosphorous and pyridinic nitrogen atoms in axial dispositions and the non-pyridinic nitrogen and both $\mathrm{CO}$ molecules pointing towards equatorial directions. This 16e species is susceptible to be hydrogenated into an $18 \mathrm{e}$ species, which is the one that presents catalytic activity for the Claisen-Tishchenko reaction of interest in this study. As shown at Scheme 3(a), two possible routes for the hydrogenation of the 16e species (pre-catalyst) might take place: either via direct hydrogenation (DH) using $\mathrm{H}_{2}$ or through protonation-hydride transfer (PHT) of an alcohol. In both cases, the principle is based on the bifunctional character of the $\mathrm{Mn}=\mathrm{N}$ bond, with both $\mathrm{Mn}$ and $\mathrm{N}$ moieties exhibiting electrophilic and nucleophilic roles, respectively. ${ }^{41}$ Once generated the hydrogenated $\left[\mathrm{Mn}^{(\mathrm{I})}(\mathrm{CO})_{2}(\mathrm{PNN})\right]-\mathrm{H}_{2}$ complex, we focus our study in the Claisen-Tishchenko reaction of a model system consisting in the esterification of acetaldehyde into ethyl acetate [see Scheme 3(b)]. In this sense, the use of only one aldehyde substrate simplifies the mechanism because it only contemplates the synthesis of a single product $\left(\mathrm{R}_{1}=\mathrm{R}_{2}\right.$ at Scheme 1$)$ during the esterification process. 
Scheme 3. (a) Possible hydrogenation routes of a bifunctional $\mathrm{Mn}=\mathrm{N}$ bond via direct hydrogenation (DH) using $\mathrm{H}_{2}$ (top) or through protonation-hydride transfer (PHT) of an alcohol (bottom). (b) Claisen-Tishchenko reaction of interest involving the condensation of acetaldehyde into ethyl acetate catalysed by a set of Mn-containing catalysts.

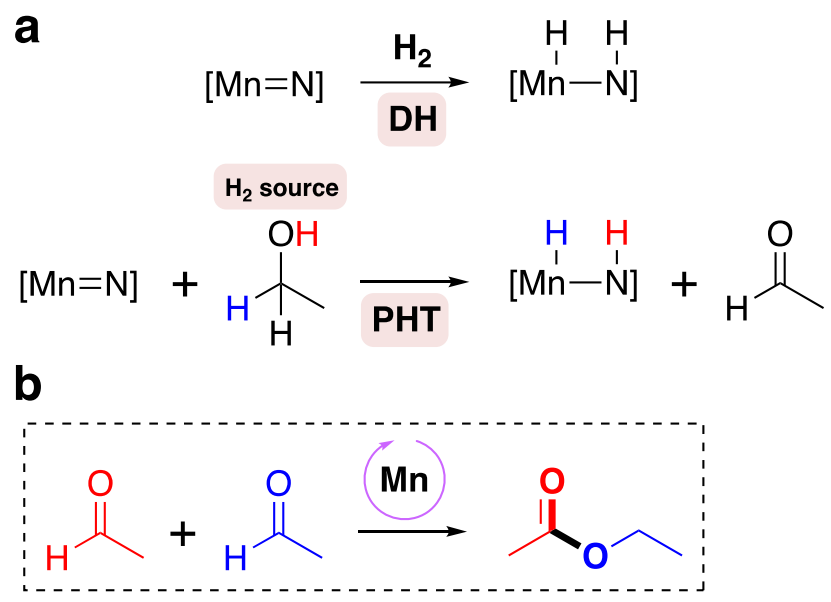

Focusing on the $\left[\mathrm{Mn}^{(\mathrm{I})}(\mathrm{CO})_{2}\left({ }^{\mathrm{Ph}} \mathrm{PNN}\right)\right](\mathrm{Mn1})$ case, Fig. 1 shows the structures and energies for both DH and PHT processes in what formally corresponds to an initiation step. For the DH route, $\mathrm{H}_{2}$ gas coordinates to $\mathrm{Mn}$ in a non-spontaneous process demanding $17.0 \mathrm{kcal} \mathrm{mol}^{-1}$ at the $\omega \mathrm{B} 97 \mathrm{XD} / \mathrm{SVP}(\mathrm{H}, \mathrm{C}, \mathrm{N}, \mathrm{O}, \mathrm{P})-\mathrm{TZVP}(\mathrm{Mn})$ level of theory in toluene as solvent. Coordinated $\mathrm{H}_{2}$ becomes slightly elongated with respect the gas phase in $0.03 \AA$, and its heterolytic cleavage via TS(IIa) exhibits an activation Gibbs energy of $21.7 \mathrm{kcal} \mathrm{mol}^{-1}$. Based on the conversion from an ideal gas at standard state of $1 \mathrm{~atm}$ to a standard state of $1 \mathrm{M}$ yields $\left(1.89 \mathrm{kcal} \mathrm{mol}^{-1}\right.$ at room temperature), ${ }^{42-44}$ this barrier would be $19.8 \mathrm{kcal} \mathrm{mol}^{-1}\left(\Delta G^{*} \mathrm{~s}=\Delta G^{\circ} \mathrm{S}-\Delta G^{\circ} \rightarrow *=21.7-1.89\right)$. As result of this, an $18 \mathrm{e}$ species is obtained ( $4.1 \mathrm{kcal} \mathrm{mol}^{-1}$ as reaction Gibbs energy) in which the non-pyridinic $\mathrm{N}$ atom becomes protonated and $\mathrm{Mn}$ atom is hydrided, i.e., causing the reduction of the $\mathrm{Mn}-\mathrm{N}$ bond. Unlike what was observed with the $16 \mathrm{e}$ species, the $18 \mathrm{e}$ species forms an octahedral structure around the $\mathrm{Mn}$ centre. As important observation, the amino-metal bond is elongated from 1.88 to $2.14 \AA$ once hydrogenated.

For the PHT route, the alcohol acts as $\mathrm{H}_{2}$ source hydrogenating the 16e species via a hydrogenation transfer process that is constituted by two main steps. In the first one, a proton transfer from the hydroxyl group to the non-pyridinic $\mathrm{N}$ atom occurs. This process is kinetically "cheap" with a calculated barrier of just $5.1 \mathrm{kcal} \mathrm{mol}^{-1}$, TS(Ib). As result of this, an outersphere alkoxy species (IIb) is formed, being at $0.8 \mathrm{kcal} \mathrm{mol}^{-1}$ with respect the referential $16 \mathrm{e}$ species (relative zero in energy) and calculating a Mn-O distance equal to $2.06 \AA$. In a second step, a hydride transfer occurs from the $\mathrm{sp}^{2}$ carbon at $\alpha$ position to Mn, representing the ratelimiting step in this initiation process with a barrier of $23.7 \mathrm{kcal} \mathrm{mol}^{-1}$. Since ethanol has been 
used to hydrogenate the 16e species, acetaldehyde is formed after the PHT, which is already the only reactant for the subsequent condensation process.

Figure 1. At top, minima and transition states (TSs) for the direct hydrogenation of the $\left[\mathrm{Mn}^{(\mathrm{I})}(\mathrm{CO})_{2}\left({ }^{(\mathrm{Ph}} \mathrm{PNN}\right)\right](\mathrm{Mn1}) 16 \mathrm{e}$ species. At bottom, analogous mechanism taking place via protonation-hydride transfer of an alcohol (hydrogenation transfer reaction). Gibbs energies $\left(100{ }^{\circ} \mathrm{C}, 1 \mathrm{~atm}\right)$ are shown in $\mathrm{kcal}^{\mathrm{mol}}{ }^{-1}$ at the $\omega \mathrm{B} 97 \mathrm{XD} / \mathrm{SVP}(\mathrm{H}, \mathrm{C}, \mathrm{N}, \mathrm{O}, \mathrm{P})-\mathrm{TZVP}(\mathrm{Mn})$ level of theory in toluene as solvent.

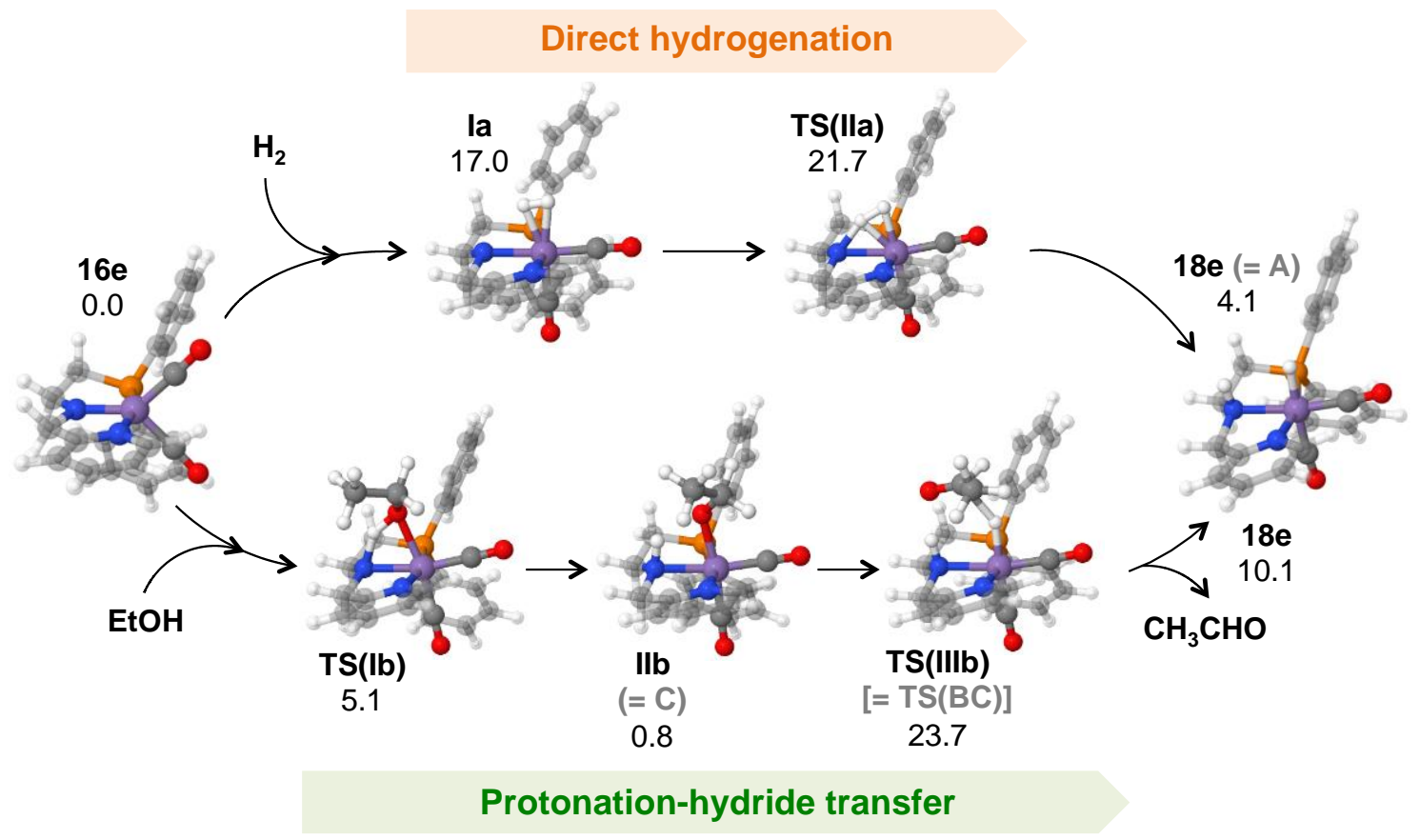

A comparison between the energy data exhibited for this process catalysed by Mn1 (i.e., with the PNN ligand containing a phenyl-substituted phosphine) and the ones in which phosphorus is linked with the aliphatic iso-propyl (Mn2) and tert-butyl (Mn3) moieties indicates that, for $\mathrm{H}_{2}$ splitting in the DH route, TS(IIa) is more energetically demanding with barriers of 26.7 and $28.6 \mathrm{kcal} \mathrm{mol}^{-1}$, respectively, or applying $\Delta G^{\circ \rightarrow *}$, equal to 24.8 and 26.7 $\mathrm{kcal} \mathrm{mol}^{-1} \cdot{ }^{42-44}$ Using as reference the Mn-alkoxy compound IIb, hydride transfers in PHT show activation energies of $23.4 \mathrm{kcal} \mathrm{mol}^{-1}$ in both cases. It should be taken into account that IIb is 5.0 and $0.8 \mathrm{kcal} \mathrm{mol}^{-1}$ more stable than the 16e species (plus ethanol) for $\mathbf{M n} \mathbf{2}$ and $\mathbf{M n} \mathbf{3}$ cases.

Once the hydrogenated manganese complex is formed, we hypothesise that this can act as active catalyst for the Claisen-Tishchenko condensation of acetaldehyde into ethyl acetate. Focusing again on the $\left[\mathrm{Mn}^{(\mathrm{I})}(\mathrm{CO})_{2}\left({ }^{\mathrm{Ph}} \mathrm{PNN}\right)\right]-\mathrm{H}_{2}$ case, Fig. 2 displays the different mechanistic steps and their corresponding calculated Gibbs reaction and activation energies.

In a first stage, the 18e species (A) interacts with acetaldehyde to form complex $\mathbf{B}$, which is located $10.9 \mathrm{kcal} \mathrm{mol}^{-1}$ uphill. This minimum is mainly supported by the presence of a $\mathrm{H}$ - 
bond of type $\mathrm{C}=\mathrm{O} \cdots \mathrm{HN}(1.89 \AA)$ and represents the immediate reactive structure prior the transition state that propitiates the hydride transfer from the $\mathrm{Mn}-\mathrm{H}$ moiety to the $\mathrm{C}\left(\mathrm{sp}^{2}\right)$ in the substrate, $\mathbf{T S}(\mathbf{B C})$. As result of this, the alkoxy compound $\mathbf{C}$ is formed, being hypothesised as a very stable entity since it is located at $-9.4 \mathrm{kcal} \mathrm{mol}^{-1}$ with respect $\mathbf{A} .{ }^{45}$ As can be seen, this set of steps in fact represents a reverse reaction of the PHT initiation process.

The protonation of the non-pyridinic $\mathrm{N}$ atom during the previous initiation process generates a stereocentre whose configuration, $(R)$ or $(S)$, is determined by which direction the $\mathrm{H}_{2}$ source approaches the catalyst. From a mechanistic point-of-view, this does not affect the hydride transfer since both $\left(R_{N}\right)$ and $\left(S_{N}\right)$ species of $\left[\mathrm{Mn}^{(\mathrm{I})}(\mathrm{CO})_{2}\left({ }^{(\mathrm{Ph} P N N}\right)\right]-\mathrm{H}_{2}$ are enantiomers. Notwithstanding, the approaching of a second aldehyde molecule to $\mathbf{C}$ entails the existence of two different energy profiles since two possible diastereoisomers, $\left(R_{N}, R\right)$ and $\left(R_{N}, S\right)$ [or their enantiomeric pairs $\left(S_{N}, S\right)$ and $\left(S_{N}, R\right)$ ], can be generated during the $\mathrm{C}-\mathrm{O}$ bond formation.

When a second acetaldehyde molecule approaches to the alkoxy moiety, an incipient $\mathrm{C}-\mathrm{O}$ bond is forming at $\mathbf{T S}(\mathbf{C D})$ via nucleophilic attack. Based on the orientation with which this approach occurs, two different stereocentres in the carbon atom could be generated: $(R)$ or $(S)$. Attending to Fig. 2, our calculations indicate that the path towards the generation of a $\mathrm{C}-\mathrm{O}$ bond in which carbon is in $(R)$ configuration has a relative barrier of $10.6 \mathrm{kcal} \mathrm{mol}^{-1}$ (purple), while for the $(S)$ case, this is accounted in $15.4 \mathrm{kcal} \mathrm{mol}^{-1}$ (grey). This activation process starts when the nucleophilic $\mathrm{O}$ atom in the alkoxy moiety is 2.18 and $1.91 \AA$ away from the $\mathrm{C}\left(\mathrm{sp}^{2}\right)$ in the second acetaldehyde molecule, however, the $\mathrm{Mn}-\mathrm{O}$ bonds remain practically similar as in the isolated outer-sphere alkoxy species C (2.07 and 2.12 vs. $2.06 \AA$ A). Although structure D represents the product after condensation, an important redistribution of charge is produced. This entails that former alkoxy and aldehyde functionalities become ester and alkoxy groups, and therefore, a new alkoxy complex is formed at $\mathbf{E}$. Based on thermodynamics, these intermediate states are also stable species located at -8.0 and $-7.4 \mathrm{kcal} \mathrm{mol}^{-1}$ with respect $\mathbf{A}$ (and also compared with those at $\mathbf{D}$, with relative energies at -1.0 and $4.2 \mathrm{kcal} \mathrm{mol}^{-1}$, respectively). Based on these results, we can conclude that the path towards the generation of an $\left(R_{N}, R\right)$ intermediate species is more favoured than for $\left(R_{N}, S\right)$ at $100{ }^{\circ} \mathrm{C}$ and 1 atm conditions. It is also suggested that the elementary steps due to condensation are kinetically accessible, at least for the substrates under study.

The catalytic cycle finalises with a "back transfer" of the hydride from the substrate to the Mn centre, being in this case produced with the hydrogen in $\alpha$ of the new alkoxy group. Attending to our DFT results, this represents the rate-limiting step with activation barriers of 16.6 and $15.8 \mathrm{kcal} \mathrm{mol}^{-1}$, respectively. As result of this, the $18 \mathrm{e}\left[\mathrm{Mn}^{(\mathrm{I})}(\mathrm{CO})_{2}\left({ }^{\mathrm{Ph}} \mathrm{PNN}\right)\right]-\mathrm{H}_{2}$ species is regenerated and the release of ethyl acetate is produced as the only product of the reaction without generation of side or waste compounds. This process is spontaneous by $14.8 \mathrm{kcal} \mathrm{mol}^{-1}$. Finally, a view in overall of the reaction mechanism makes us to conclude that the Mn centre, as 
the only active site of this process, has a dual role. First, acting as hydride borrowing, and second, leading the formation and stabilisation of an alkoxy compound that promotes the $\mathrm{C}-\mathrm{O}$ bond formation in a central step of formal condensation.

Figure 2. Gibbs energy diagram (in $\mathrm{kcal} \mathrm{mol}^{-1}$ ) for the Claisen-Tishchenko condensation of acetaldehyde into ethyl acetate catalysed by the hydrogenated $\left[\mathrm{Mn}^{(\mathrm{I})}(\mathrm{CO})_{2}\left({ }^{\mathrm{Ph}} \mathrm{PNN}\right)\right]-\mathrm{H}_{2} 18 \mathrm{e}$ species. Purple and grey paths refer to the respective generation of $(R)$ or $(S)$ stereocentres during the formation of the $\mathrm{C}-\mathrm{O}$ bond at $\mathbf{T S}(\mathbf{C D})$. Calculations are shown at the $\omega \mathrm{B} 97 \mathrm{XD} / \mathrm{SVP}(\mathrm{H}, \mathrm{C}, \mathrm{N}, \mathrm{O}, \mathrm{P})-\mathrm{TZVP}(\mathrm{Mn})$ computational level in toluene as solvent and at $100{ }^{\circ} \mathrm{C}$ and $1 \mathrm{~atm}$ reaction conditions. Note: for simplicity, $\mathbf{P}=\mathrm{PPh}_{2}$.

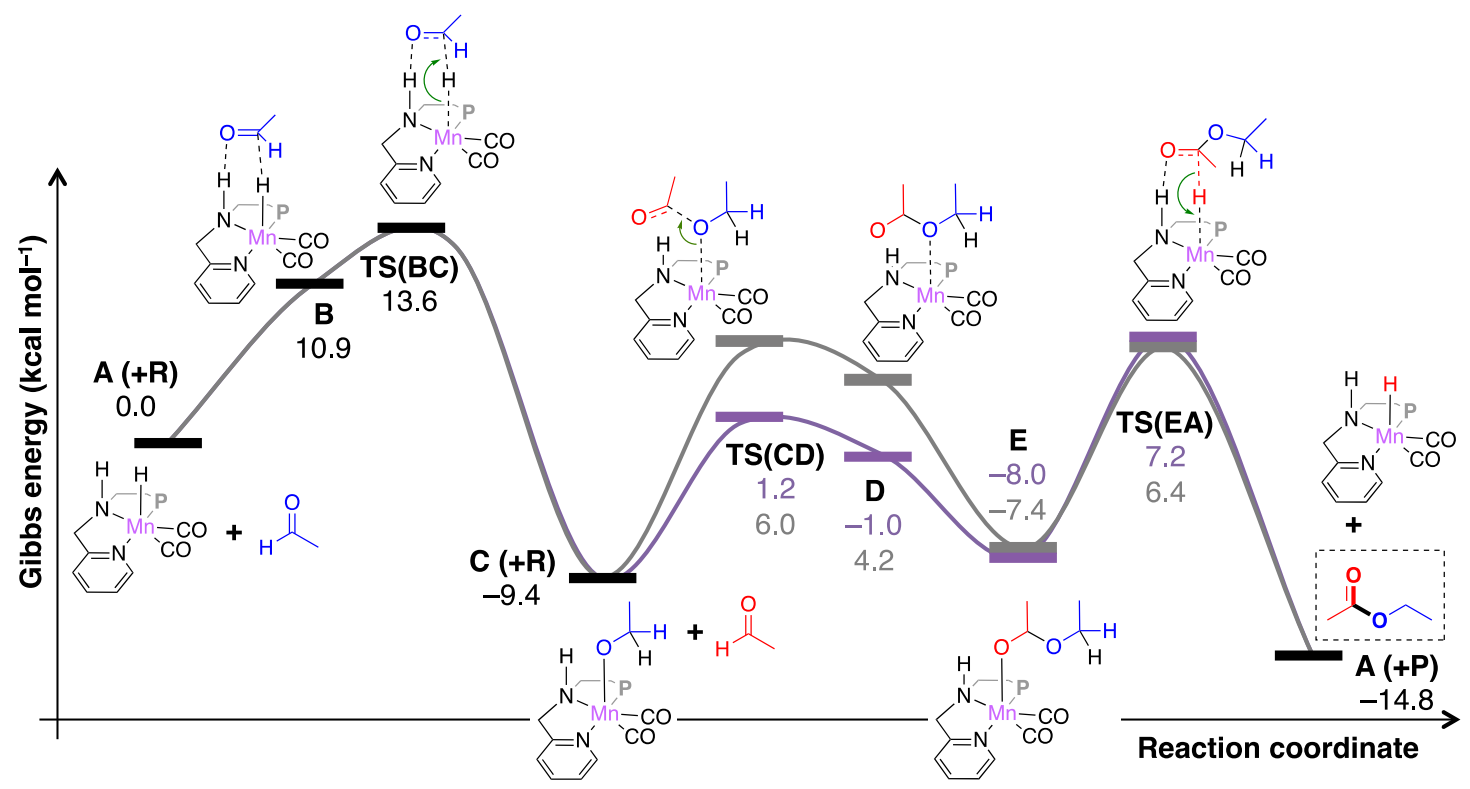

A comparison between these data and the ones offered by the complexes containing a PNP ligand in which phosphorus is linked with the aliphatic iso-propyl and tert-butyl moieties reveals that, both steps, $\mathrm{C}-\mathrm{O}$ bond formation and hydride transfer from the substrate to the $\mathrm{Mn}$ centre are more energetically demanding. Since tert-butyl has more steric effects that iso-propyl, activation energies are also more pronounced. Specifically, TS(CD) and TS(EA) exhibit barriers of 12.5 and $18.9 \mathrm{kcal} \mathrm{mol}^{-1}$ for the $\left(R_{N}, R\right)$ path and 15.0 and $18.2 \mathrm{kcal} \mathrm{mol}^{-1}$ for $\left(R_{N}, S\right)$ when catalysed by the $18 \mathrm{e}\left[\mathrm{Mn}^{(\mathrm{I})}(\mathrm{CO})_{2}\left({ }^{i \mathrm{Pr}} \mathrm{PNN}\right)\right]-\mathrm{H}_{2}$ species. When catalysis is done by assistance of $\left[\mathrm{Mn}^{(\mathrm{I})}(\mathrm{CO})_{2}{ }^{\left({ }^{\mathrm{B} u} \mathrm{PNN}\right)}\right]-\mathrm{H}_{2}$, these values increase to 13.7 and $21.8 \mathrm{kcal} \mathrm{mol}^{-1}$ for path $\left(R_{N}, R\right)$ and 18.7 and $19.7 \mathrm{kcal} \mathrm{mol}^{-1}$ for path $\left(R_{N}, S\right)$.

\section{CONCLUSIONS}

In summary, the $16 \mathrm{e}$ species $\left[\mathrm{Mn}^{(\mathrm{II})}(\mathrm{CO})_{2}\left({ }^{\mathrm{Ph}} \mathrm{PNN}\right)\right](\mathrm{Mn1}),\left[\mathrm{Mn}^{(\mathrm{II})}(\mathrm{CO})_{2}\left({ }^{i \mathrm{Pr}} \mathrm{PNN}\right)\right](\mathrm{Mn2})$, and $\left[\mathrm{Mn}^{(\mathrm{I})}(\mathrm{CO})_{2}{ }^{\left.\left({ }^{\mathrm{B} u} \mathrm{PNN}\right)\right]}\right.$ (Mn3) can be hydrogenated via direct hydrogenation (DH) or by hydrogenation transfer through protonation-hydride transfer (PHT) of an alcohol. The generated 
18e species, $\left[\mathrm{Mn}^{(\mathrm{I})}(\mathrm{CO})_{2}(\mathrm{PNN})\right]-\mathrm{H}_{2}$, have been investigated as potential catalysts for the Claisen-Tishchenko reaction in a model system consisting in the esterification of acetaldehyde into ethyl acetate. According to data at the $\omega \mathrm{B} 97 \mathrm{XD} / \mathrm{SVP}(\mathrm{H}, \mathrm{C}, \mathrm{N}, \mathrm{O}, \mathrm{P})-\mathrm{TZVP}(\mathrm{Mn})$ computational level in toluene as solvent, the approaching of a second aldehyde molecule to the alkoxy [Mn]-OEt species exhibit barriers of 10.6, 12.5, and $13.7 \mathrm{kcal} \mathrm{mol}^{-1}$, respectively, for paths $\left(R_{N}, R\right)$ which lead to the formation of a $\mathrm{C}-\mathrm{O}$ bond $\left(100{ }^{\circ} \mathrm{C}, 1 \mathrm{~atm}\right.$ reaction conditions). This formal esterification step is not the rate-limiting step, which corresponds to the "back transfer" of the hydride from the substrate to the Mn centre. As imposed by kinetics control, the preferred $\left(R_{N}, R\right)$ pathway exhibit barriers for this hydride transfer step of 16.6, 18.9, and 21.8 $\mathrm{kcal} \mathrm{mol}{ }^{-1}$, in each case, rendering the complex containing the phenyl-substituted phosphine as the most active of this series, i.e., compared with those in which the phosphorous atoms are linked with the $i \operatorname{Pr}$ or $t \mathrm{Bu}$ aliphatic groups. Different to hydrogen transfer reactions of classical bifunctional catalysts, $\mathrm{Mn}$ is the solely active site involved in both elemental steps of hydride borrowing and $\mathrm{C}-\mathrm{O}$ bond formation. Finally, we sincerely hope that our findings might stimulate further interest on this area.

\section{ACKNOWLEDGMENTS}

LMA is an ULPGC Postdoc Fellow, and thanks Universidad de Las Palmas de Gran Canaria (ULPGC). This research has been supported by the King Abdullah University of Science and Technology (KAUST). Gratitude is also due to the KAUST Supercomputing Laboratory using the supercomputer Shaheen II for providing the computational resources. LMA also acknowledges the Scientific Committee of ESPA 2018 Conference for selecting him as speaker.

\section{CONFLICT OF INTERESTS}

Authors declare no competing financial interests.

\section{REFERENCES}

1. Otera J, Nishikido J, Esterification: Methods, Reactions, and Applications, Second Edition, Wiley - VCH Verlag GmbH \& Co. KGaA, 2010.

2. Chirik P, Morris R (2015) Accounts of Chemical Research 48:2495-2495.

3. Schrock RR, Osborn JA (1976) Journal of the American Chemical Society 98:2134-2143.

4. Tani K, Iseki A, Yamagata T (1999) Chemical Communications, DOI: 10.1039/A905765J:1821-1822.

5. Shen R, Chen T, Zhao Y, Qiu R, Zhou Y, Yin S, Wang X, Goto M, Han L-B (2011) Journal of the American Chemical Society 133:17037-17044.

6. Neumann KT, Klimczyk S, Burhardt MN, Bang-Andersen B, Skrydstrup T, Lindhardt AT (2016) ACS Catalysis 6:4710-4714.

7. Richmond E, Moran J (2015) The Journal of Organic Chemistry 80:6922-6929. 
8. Tokmic K, Fout AR (2016) Journal of the American Chemical Society 138:13700-13705.

9. Korytiaková E, Thiel NO, Pape F, Teichert JF (2017) Chemical Communications 53:732-735.

10. Brzozowska A, Azofra LM, Zubar V, Atodiresei I, Cavallo L, Rueping M, ElSepelgy O (2018) ACS Catalysis 8:4103-4109.

11. Das UK, Chakraborty S, Diskin-Posner Y, Milstein D (2018) Angewandte Chemie 130:13632-13636.

12. Glatz M, Stöger B, Himmelbauer D, Veiros LF, Kirchner K (2018) ACS Catalysis 8:4009-4016.

13. Borghs JC, Lebedev Y, Rueping M, El-Sepelgy O (2019) Organic Letters 21:7074.

14. Borghs JC, Azofra LM, Biberger T, Linnenberg O, Cavallo L, Rueping M, ElSepelgy O (ChemSusChem 0.

15. Kumar A, Espinosa-Jalapa NA, Leitus G, Diskin-Posner Y, Avram L, Milstein D (2017) Angewandte Chemie International Edition 56:14992-14996.

16. Espinosa-Jalapa NA, Kumar A, Leitus G, Diskin-Posner Y, Milstein D (2017) Journal of the American Chemical Society 139:11722-11725.

17. Jang YK, Krückel T, Rueping M, El-Sepelgy O (2018) Organic Letters 20:77797783.

18. Gorgas N, Kirchner K (2018) Accounts of Chemical Research 51:1558-1569.

19. Kallmeier F, Kempe R (2018) Angewandte Chemie International Edition 57:4660.

20. Luque-Urrutia JA, Solà M, Milstein D, Poater A (2019) Journal of the American Chemical Society 141:2398-2403.

21. Masdemont J, Luque-Urrutia JA, Gimferrer M, Milstein D, Poater A (2019) ACS Catalysis, DOI: 10.1021/acscatal.8b04175:1662-1669.

22. Claisen L (1887) Berichte der deutschen chemischen Gesellschaft 20:646-650.

23. Dzik WI, Gooßen LJ (2011) Angewandte Chemie International Edition 50:11047-11049.

24. Tishchenko VE (1906) J. Russ. Phys. Chem. Soc. 38:355-418.

25. Tishchenko VE (1906) J. Russ. Phys. Chem. Soc. 38:482-540.

26. Simon M-O, Darses S (2010) Advanced Synthesis \& Catalysis 352:305-308.

27. Ogoshi S, Hoshimoto Y, Ohashi M (2010) Chemical Communications 46:33543356.

28. Hoshimoto Y, Ohashi M, Ogoshi S (2011) Journal of the American Chemical Society 133:4668-4671.

29. Tejel C, Ciriano MA, Passarelli V (2011) Chemistry - A European Journal 17:91-95.

30. Morris SA, Gusev DG (2017) Angewandte Chemie International Edition 56:6228-6231.

31. Kadassery KJ, MacMillan SN, Lacy DC (2018) Dalton Transactions 47:1265212655.

32. Das UK, Ben-David Y, Leitus G, Diskin-Posner Y, Milstein D (2019) ACS Catalysis 9:479-484.

33. Zubar V, Lebedev Y, Azofra LM, Cavallo L, El-Sepelgy O, Rueping M (2018) Angewandte Chemie International Edition 57:13439-13443.

34. Chai J-D, Head-Gordon M (2008) Physical Chemistry Chemical Physics 10:6615-6620.

35. Grimme S (2006) Journal of Computational Chemistry 27:1787-1799. 
36. Weigend F, Ahlrichs R (2005) Physical Chemistry Chemical Physics 7:32973305.

37. Kudin KN, Scuseria GE, Cancès E (2002) The Journal of Chemical Physics 116:8255-8261.

38. Peng C, Ayala PY, Schlegel HB, Frisch MJ (1996) Journal of Computational Chemistry 17:49-56.

39. Tomasi J, Mennucci B, Cammi R (2005) Chemical Reviews 105:2999-3094.

40. Frisch MJ, Trucks GW, Schlegel HB, Scuseria GE, Robb MA, Cheeseman JR, Scalmani G, Barone V, Mennucci B, Petersson GA, Nakatsuji H, Caricato M, Li X, Hratchian HP, Izmaylov AF, Bloino J, Zheng G, Sonnenberg JL, Hada M, Ehara M, Toyota K, Fukuda R, Hasegawa J, Ishida M, Nakajima T, Honda Y, Kitao O, Nakai H, Vreven T, Montgomery Jr. JA, Peralta JE, Ogliaro F, Bearpark M, Heyd JJ, Brothers E, Kudin KN, Staroverov VN, Kobayashi R, Normand J, Raghavachari K, Rendell A, Burant JC, Iyengar SS, Tomasi J, Cossi M, Rega N, Millam NJ, Klene M, Knox JE, Cross JB, Bakken V, Adamo C, Jaramillo J, Gomperts R, Stratmann RE, Yazyev O, Austin AJ, Cammi R, Pomelli C, Ochterski JW, Martin RL, Morokuma K, Zakrzewski VG, Voth GA, Salvador P, Dannenberg JJ, Dapprich S, Daniels AD, Farkas Ö, Foresman JB, Ortiz JV, Cioslowski J, Fox DJ, Gaussian09 (revision D.01), Gaussian, Inc., Wallingford CT, 2009.

41. Eisenstein O, Crabtree RH (2013) New Journal of Chemistry 37:21-27.

42. Kelly CP, Cramer CJ, Truhlar DG (2005) Journal of Chemical Theory and Computation 1:1133-1152.

43. Kelly CP, Cramer CJ, Truhlar DG (2006) The Journal of Physical Chemistry B 110:16066-16081.

44. Bryantsev VS, Diallo MS, Goddard Iii WA (2008) The Journal of Physical Chemistry B 112:9709-9719.

45. Nguyen DH, Trivelli X, Capet F, Paul J-F, Dumeignil F, Gauvin RM (2017) ACS Catalysis 7:2022-2032. 